\title{
Vladavina svetovnega razvrščanja v izobraževanju: politika in praksa raziskave PISA
}

Paul Stubbs, Ekonomski inštitut Zagreb

članku s spoznanji raziskav o prenosu in prevajanju javnih politik ter o nastajanju globalne vladavine, moči in vpliva prispevam kritičen pogled na OECD, zlasti na njen Program mednarodne primerjave dosežkov učencev in učenk ( $v$ nadaljevanju raziskava PISA). Osredotočam se zlasti na vprašanje, kako je raziskava PISA lahko postala tako samoumevno primerjalno merilo nacionalnih dosežkov v izobraževanju, kljub številnim kritikam v literaturi in celo odprtemu pismu, ki ga je podpisalo veliko število znanih pedagogov (Meyer in Zahedi, 20I4). $\mathrm{V}$ nekem smislu je članek poziv $\mathrm{k}$ bolj poglobljenemu razumevanju raziskave PISA s strani pedagogov, oblikovalcev politik, medijev in javnosti. V njem prikažem, da je raziskava PISA postala eden glavnih instrumentov »na podatkih temelječe politike« izobraževanja, čeprav - ali na sprevržen način morda prav zato, ker - sloni na precej trhlih temeljih in predpostavljenih vzročnih povezavah, ki so $\mathrm{v}$ najboljšem primeru nedokazane in temeljijo na globoko zaskrbljujočih, determinističnih in redukcionističnih ideoloških predpostavkah ter na odločnem zavračanju obravnave nacionalnih kontekstov, ki bi lahko postavili pod vprašaj produkcijo dekonstekstualiziranih, domnevno univerzalnih kazalnikov. Prepad med domnevnim pomenom rezultatov raziskave PISA in njihovim vplivom na izobraževalne politike na eni strani ter njihovim dejanskim pomenom in vlogo, ki bi jo morali imeti v bolj celostnem pristopu k izobraževalnim reformam, na drugi strani, je zdaj tako širok, da se zdi domala nepremostljiv.

$\mathrm{V}$ članku se osredotočam na tri različne, čeprav medsebojno povezane ravni: na ekonomsko in politično ideologijo, na kateri temelji raziskava PISA, uporabo in zlorabo raziskave PISA v izobraževalni politiki in na 
potencialne neposredno negativne vplive raziskave PISA na razvoj učencev in učenk, blagostanje učiteljev in učiteljic ter možnosti za kritično, progresivno pedagogiko. Moj namen ni, da bi članek razumeli kot poskus pristranske kritike raziskave PISA. Vendar pa v njem izražam zaskrbljenost nad tem, da je raziskava PISA postala tako izkrivljena in tako osredotočena na najvidnejše rezultate namesto na množico dragocenih podatkov, ki jih proizvede, da ji zato manjka prilagodljivosti, ki jo potrebujejo dobri sistemi evalvacije. Članek črpa navdih iz nadvse zanimivega prispevka Petra Dahler-Larsena (20I2), v katerem je avtor zastavil devetnajst vprašanj, na temelju katerih bi morali presojati sistem evalvacije. Za namen pričujočega članka sta posebej pomembni dve izmed njih: I) »Ali je sistem evalvacije prežet $\mathrm{z}$ vseobsegajočo ideologijo, zaradi katere opravičuje samega sebe? «2) »Ali ta sistem evalvacije ... zagotavlja odzivnost na smiselno kritiko? « V članku prikažem, da moramo neogibno na prvo vprašanje odgovoriti $z$ da in na drugo $z$ ne.

\section{PISA kot neoliberalna lepljenka}

Raziskava PISA izhaja iz sovpadanja neoliberalne ideologije, omejitev novega javnega managementa, oživitve teorije človeškega kapitala v kontekstu »kognitivnega kapitalizma globalnega dometa «, vladanja s številkami in vzpona OECD kot »mehke oblasti «, ki se odziva zlasti na skrb Združenih držav Amerike za lastno globalno konkurenčnost. OECD je postala posebna vrsta »transnacionalne, iz stroke izhajajoče institucije «, če si sposodim izraz Asuncion St. Clair (2006), ki soproizvaja tako vednost kot njeno recepcijo in uporabo za oblikovanje politik v pristojnosti več področij. Znamka PISA temelji na konstrukciji domnevno neposrednih povezav med učenjem, spretnostmi, ocenjevanjem in dosežki v meritvah PISA. Veliko je bilo že napisanega o tem, kako sta OECD in PISA pridobili prevlado v izvajanju preverjanja znanja na račun Mednarodne organizacije za merjenje učinkov izobraževanja in njene študije, Mednarodne raziskave trendov $\mathrm{v}$ znanju matematike in naravoslovja (TIMSS), ter Mednarodne raziskave bralne pismenosti (PIRLS), in sicer - vsaj delno - zaradi trditev, da raziskava PISA ni vezana na kurikulum, se pravi, da meri spretnosti in kompetence, ki so potrebne v sodobni ekonomiji neodvisno od nacionalnih kurikulov (Morgan, 2009; Hanberger, 2014). Zdrs od »družbe $\ll \mathrm{k} \gg$ ekonomiji $\ll$ v diskurzu PISA nas ne sme presenetiti glede na to, da OECD vidi svoje poslanstvo v »boljših politikah za boljše življenje « in v »pripravljanju sveta za boljši jutri« (https://www.oecd.org/ about/), zlasti, kar zadeva dejavno udeleženost vseh v konkurenčni globalni ekonomiji prostega trga. Vsi lahko sodelujejo, vendar bomo zmeraj imeli zmagovalce in poražence, zato je pomembno, da razlikujemo med 
državami, ki dosegajo nadpovprečne dosežke, in tistimi, ki imajo podpovprečne. Nekateri upravičeno vidijo naraščajoče število sodelujočih držav $\mathrm{z}$ vsakim ciklom raziskave PISA in vključevanje vse več držav, ki niso članice OECD, kot pokazatelj širjenja hegemonije OECD (Sjøberg, 20rs; 20I8). Sam menim, da je enako zanimiva vključitev delov Kitajske in nikoli Kitajske kot celote - ne pozabimo, da so v raziskavi iz leta $2018 \mathrm{v}$ branju in matematiki med štirimi državami v samem vrhu kitajske province, ki reprezentirajo Kitajsko kot državo (Beijing, Šanghaj, Džiangsu in Žedžiang oziroma B-S-J-Z) ter ločeno Singapur, Makao in Hong Kong (https://www.oecd.org/pisa/PISA-results_ENGLISH.png). To omogoča - morda naključni - obrat k Aziji kot primerjalnem merilu, namesto $\mathrm{k}$ skandinavskim državam blaginje, ki so bile v samem vrhu v predhodnih ciklih.

Raziskava PISA je seveda le en primer kombinacije treh tiranij: številk, povprečij in primerjav. Številkam ne moremo ugovarjati, ker številke govorijo same zase, imamo jih za objektivno, veljavno, nevtralno in tehnično orodje in ne za simbolne reprezentacije, ki nam govorijo, kaj šteje in kaj ne. Trditi, z besedami Williama Bruca Camerona, ki jih pogosto pripisujejo Einsteinu, »da se vsega, kar šteje, ne da prešteti«, pomeni tvegati, da odpremo prostor za sodobno maksimo: »Vse se da izmeriti in meritve so vse.« Številke skrivajo kompleksno paleto vrednot, sodb, odločitev, kompromisov in včasih celo čudežnih statističnih zvijač, ki pojasnjujejo njihov nastanek in ustvarjajo dozdevno nevprašljivo logiko, da dosežki raziskave PISA natančno merijo tako pomembne stvari, da bi morale biti temelj »globalnega polja primerjalne uspešnosti« (Lingard in Grek, 2008). Izvajanje raziskave PISA je sodobni ekvivalent zgodbe o cesarjevih novih oblačilih ali pa je - glede na to, da razkritje o cesarjevi goloti očitno nima učinka - morda bolj točna primerjava s preročiščem v Delfih, kakor predlaga Gorur (2014).

\section{PISA kot politika}

Glede na to, da se politika ne giblje sama od sebe, temveč je oblikovana za to, da se giblje in je v procesu vedno prevedena, poročila, ki navajajo, da je raziskava PISA prispevala h globalnemu zbliževanju izobraževalnih politik, precenjujejo njen vpliv. Nacionalne države, ki so uvrščene na mednarodno lestvico dosežkov v raziskavi PISA, so namreč veliko več kot zgolj »vsebniki« politik; ko se politike gibljejo, kot trdimo v knjigi Making Policy Move, so predmet »najrazličnejših srečanj, ki jih preoblikujejo, prirejajo, si jih prilaščajo in prilagajajo « (Clarke et al., 20I5: 15); ta srečanja se med seboj razlikujejo zaradi natanko tistih $\gg$ kontekstov $\ll$, ki si jih preizkusi v okviru raziskave PISA prizadevajo izbrisati. Čeprav je vsak »PISA 
učinek « kompleksen in kontingenten, nedvomno obstaja. Pomislimo le na naravo spektakla skrbno koreografiranih razglasitev rezultatov raziskave PISA - embargi, promocijski dogodki, dobro pripravljene informacije za medije, prikrojena sporočila, poudarjanje uvrstitev, raba grafičnih prikazov in tako naprej -, vse se zdi oblikovano tako, da v državah, ki niso med »najuspešnejšimi« ali »hitro napredujočimi« (D’Agnese, 2015), s »PISA šoki $<$, kot jih imenujejo v literaturi, proizvede odzive $s$ »hitro politiko « (Peck in Theodore, 20Is). Podobno kot v ligi prvakov: tisto, kar šteje, niso toliko dosežene točke, kolikor uvrstitev na lestvici, ki v sebi nosi neki trajni pomen za prihodnost, saj najuspešnejše države postanejo referenčne, tiste, ki so zdrsnile po lestvici navzdol, pa iščejo hitre rešitve za izboljšanje stanja.

Seveda se raziskava PISA ne umešča do enake mere v vse nacionalne sisteme preverjanja znanja, politiki in oblikovalci javnih politik pa lahko sporočilo, ki izhaja iz uvrščenosti na lestvico PISA, prikrojijo po svoje in ga celo ignorirajo - vendar se morajo za to potruditi. PISA šoki vplivajo na programe izobraževalnih reform $\mathrm{v}$ številnih državah - v literaturi so najpogosteje omenjene Danska, Japonska in Nemčija (Breakspear, 20I2) -, natanko na tiste, ki imajo dobro financirane, a premalo uspešne izobraževalne sisteme. Premalo je bilo narejenega na poznavanju vplivov raziskave PISA na oblikovanje politik v postsocialističnih državah, čeprav se bo Estonija $\mathrm{z}$ uvrstitvijo višje na lestvici verjetno znašla v središču pozornosti. V svojem novejšem prispevku Jakubowski (2018) za Poljsko ugotavlja, da ima v tej državi raziskava PISA monopol v javni in medijski pozornosti in da so rezultati Raziskave bralne pismenosti (PIRLS) ter Raziskave matematične in naravoslovne pismenosti (TIMMS), ki se jima je Poljska pridružila pozneje, obravnavane zgolj s strani strokovnjakov. Zanimivo je, da je vladajoča stranka Zakon in pravičnost $\mathrm{v}$ svoji retoriki proti establišmentu nezaupljiva do transnacionalnih primerjalnih analiz, ki jih promovirajo mednarodne organizacije, in omenja, da bi reforme, ki jih nekateri pripisujejo izboljšanim rezultatom $\mathrm{v}$ raziskavi PISA, prav lahko odpravili. Jakubowski (20r8) trdi, da je oblikovanje politik zgolj na strokovnem temelju, ki ne upošteva občutenja ljudstva in prevladujočih političnih trendov, pogosto kontraproduktivno.

Opozorili smo že (Stubbs, 2019) na izjemni pomen statistike OECD o družbeno-ekonomskem statusu in spolu, ki pogosto izhajajo iz meritev PISA. Hkrati se »PISA cirkus « navadno osredotoča bolj na povprečja in veliko manj na enakost možnosti, ki je zvedena na tehnično vprašanje. Raziskava PISA se skoraj ne osredotoča na etničnost, vrzel med urbanim in ruralnim ali na posebne potrebe učencev in učenk, tako da prihaja do očitnega razkoraka med rezultati raziskave PISA in razpravami 
o pravičnosti, mobilnosti in inkluziji v izobraževanju. Bolje rečeno, osredotočanje na najboljše rezultate raziskave PISA je le vrh ledene gore, ki še bolj odvrača pozornost od teh vprašanj. In tudi če bi posvečali več pozornosti temu, kako se lahko uvrstimo v kvadrant visoka uspešnost/visoka enakost (če bi enakost in uspešnost lahko zvedli na matrico $2 \times 2$ ), je to vse prej kot lahko doseči - Avstralija se je v triletnem obdobju iz kvadranta, ki označuje nizko enakost, premaknila v kvadrant, ki označuje visoko enakost, predvsem zaradi sprememb v opredelitvah, do katerih je prišlo med letoma 2000 in 2003 (Gorur, 2014).

\section{PISA kot dekontekstualizirano znanje}

$\mathrm{Na}$ tej točki se obračam k zapletenemu vprašanju kulture in konteksta, pri čemer imam $v$ mislih trditev o univerzalni uporabljivosti preverjanja v okviru raziskave PISA in tistega, kar preverja. Tudi argument, da učencem in učenkam PISA preizkus ni pomemben, medtem ko je za državo njena uvrstitev na lestvici dosežkov pomembna, ne drži univerzalno: vzemimo razliko med kakšno azijsko ali latinskoameriško državo, kjer učenci in učenke na preverjanju znanja v okviru raziskave PISA najprej skupaj zapojejo državno himno, potem pa jim povedo, kako pomembno je to preverjanje za ponos naroda (Lingard in Sellar, 2013), in Združenimi država$\mathrm{mi}$, ki so vključene $\mathrm{v}$ rezultate vsakega cikla, čeprav redno presegajo dovoljeni skupni -odstotni delež izključenih učencev in učenk na ravni šol in znotraj šol, ki ga določa protokol PISA. Je res naključje, da država, ki nikoli ni dosegla zahtevanega deleža vključenosti na ravni šol, prispeva okoli $25 \%$ sredstev proračuna OECD (Eivers, 2010)?

Številni dvomijo v odločitev, da se preverja petnajstletnike po vsem svetu ne glede na njihovo stopnjo šolanja $\mathrm{v}$ nacionalnih izobraževalnih sistemih in prehod iz izobraževanja $\mathrm{v}$ zaposlitev (Eivers, 20IO). V kontekstu globalnega digitalnega razkoraka številni dvomijo tudi v naraščajoče opiranje na preverjanje znanja s pomočjo računalnika. Spet drugi opozarjajo, da so rezultati PISA na ravni držav izjemno slabi napovedovalci dosežkov države v Globalnem podjetniškem monitorju (Sjøberg, 20I5). Potemtakem je, tudi če vas prepriča agenda »globalne kompetence za globalno konkurenčnost «, med tistim, kar naj bi raziskava PISA preverjala, in tistim, kar dejansko preverja, vse polno protislovij. »Spremembe v mišljenju skozi čas « pač ne moremo preverjati s časovno omejenim testom (D’Agnese, 2015). Kako lahko pojasnimo dejstvo, da rezultati »naravoslovne pismenosti« obratno korelirajo $\mathrm{z} \gg \mathrm{zanimanjem}$ za naravoslovje «? (Sjøberg, 20I8) Morda je vzrok v tem, da »izigrati sistem« (Stevenson, 2017) dejansko pomeni zmanjšati število elementov na raziskovanju temelječega naravoslovnega izobraževanja, terenskega dela, izvajanja poskusov 
$v$ resničnem svetu in tako naprej, ker »teh PISA ne preverja«. Kako lahko OECD države odvrne od tega, da ne bi preprosto prilagodile svojih izobraževalnih sistemov v smislu priprave učencev in učenk na preverjanje znanja v raziskavi PISA? Kot sporna sta se pokazala tudi sestavljanje in, kar je ključno, prevajanje testnih vprašanj - na primer prevodi iz angleščine in francoščine v nemščino so bili za I5 \% daljši od izvirnikov in so imeli značilno višji delež redko uporabljanih izrazov (Eivers, 20ı). Poleg tega ni povsem točno, če preizkuse PISA opišemo kot neodvisne od kurikulov; $\mathrm{v}$ resnici imajo boljše rezultate tiste države, v katerih preverjanje v okviru raziskave PISA najbolj prepričljivo odraža elemente nacionalnega kurikula. Kakšno je razmerje med tako imenovanim praktičnim, vendar dekontekstualiziranim znanjem, ki ga meri raziskava PISA, in disciplinarnim znanjem? Zakaj so izbrane kompetence povezane $\mathrm{z}$ nekaterimi disciplinami, zlasti z matematiko, branjem, naravoslovjem in tehnologijo, z drugimi pa ne? Ali narava preizkusov pomeni, da imajo bralne spretnosti nepotrebno velik vpliv na uspeh na drugih področjih (Eivers, 20I0)?

\section{PISA kot neodgovorno vladanje}

Končno pa lahko postavimo pod vprašaj tudi odgovornost načina preverjanja, pri katerem so uporabljene statistične tehnike, ki so preveč kompleksne za laično razpravo in nikoli povsem razkrite. Ali je OECD v svoji tesni povezanosti $\mathrm{z} \gg$ izobraževalnim poslom « - zlasti s profitno družbo Pearson, ki pridobiva 80 \% svojih prihodkov iz izobraževanja in trži komplete gradiva za testiranje, podobne preizkusom PISA, ter ponuja svetovanje po vsem svetu - pristranska v odgovornosti do drugih deležnikov (Lingard in Sellar, 2013; Sjøberg, 2015)? PISA ni edina odgovorna za osiromašenje kakovosti poučevanja in učenja $\mathrm{v}$ šolah ter za potiskanje prizadevanj učiteljev in učencev na, kot bi rekel Jamie Peck, »tekoči trak, ki ga je izdelal nekdo drug« (Peck, 2002 v Baird et al., 2016), in še manj za odmik od razsvetljenskih idej pastoralne skrbi, spodbujanja talenta, osebnega razvoja in kultiviranja razmišljajočih državljanov, ki slavijo različnost in raznolikost. Toda PISA je oblikovana po podobi instrumentaliziranega izobraževalnega sistema in prispeva $\mathrm{k}$ njegovi nenehni reprodukciji.

\section{Sklepi}

Če povzamem, preverjanje $\mathrm{v}$ okviru raziskave PISA in $\gg$ performativno dramo« uvrščanja na mednarodno lestvico dosežkov vsake tri leta lahko imamo za enega izmed številnih primerov odmikanja od bolj »neposrednih« oblik upravljanja izobraževanja in približevanja kompleksnejšim, posrednim, distanciranim in mreženim oblikam (Grek in Lindgren, 2015: I). Je ključna sestavina neoliberalne oblike politične racionalnosti, ki ne 
opisuje le »stanja stvari, kakršno je«, temveč je tudi implicitno, če ne eksplicitno, vizija »stanja stvari, kot bi moralo biti«. Povezave med procesi in odnosi med dejavniki izobraževanja, na katerih temelji raziskava PISA, seveda še zdaleč niso neodvisne - PISA si mora zelo prizadevati, da bi čim bolj zmanjšala tveganje izgube dobrega imena, ki je posledica njenih številnih protislovij. Kritično raziskovanje kot prispevek h kritični pedagogiki, povezani z zagovorniškimi pobudami, ki prevprašujejo na raziskavi PISA temelječi model izobraževanja, mora nujno postati sestavni del javnega preverjanja izobraževalnih sistemov in razvrščanja v izobraževanju.

\section{Literatura}

Baird, J-A., Johnson, S., Hopfenbeck, T. N., Isaacs, T., Sprague, T., Stobart, G., in Yu, G. (2016) On the Supranational Spell of PISA in Policy. Educational Research 58(2), str. I2I-138.

Breakspear, S. (2012) The policy impact of PISA: An exploration of the normative effects of international benchmarking in school system performance. OECD Education Working Papers no. 71. Spletna stran: https://www.oecd-ilibrary.org/education/ the-policy-impact-of-pisa_5kgfdfqffr28-en.

Clarke, J., Bainton, D., Lendvai, N., in Stubbs, P. (2015) Making policy move: Towards a politics of translation and assemblage. Bristol: Policy Press.

D'Agnese, V. (2015) PISA's colonialism: Success, money, and the eclipse of education. Power \& Education 7(I), str. 56-72.

Dahler-Larsen, P. (2012) Evaluation as a situational or a universal good?. Scandinavian Journal of Public Administration 16(3), str. 29-46.

Eivers, E. (2010) PISA: issues in implementation and interpretation. The Irish Journal of Education 38, str. 94-118.

Gorur, R. (2014) Towards a Sociology of Measurement in Educational Policy. European Educational Research Journal I3(I), str. 58-72.

Grek, S., in Lindgren, J. (2015) Introduction. V Grek, S., in Lindgren, J. (ur.). Governing by inspection. London: Routledge.

Hanberger, A. (2014) What PISA intends to and can possibly achieve: A critical programme theory analysis. European Educational Research Journal ${ }_{13}(2)$, str. $167-180$.

Jakubowski, M. (2018) The Use and Misuse of PISA results in Poland. V Volante, L. (ur.). The PISA effect on global educational governance. London: Routledge.

Lingard, B., in Grek, S. (2008) The OECD, indicators and PISA: An exploration of events and theoretical perspectives. ESRC/ESF Project on Fabricating Quality in Education, Working Paper 2. Spletna stran: 
https://www.academia.edu/I359394/The_OECD_indicators_and_PISA_ An_exploration_of_events_and_theoretical_perspectives.

Lingard, B., in Sellar, S. (2013) Globalisation and social of education policy: The case of PISA. V Brooks, R., McCormack, M., in Bhopal, K. (ur.) Contemporary Debates in the Sociology of Education. London: Palgrave MacMillan.

Meyer, H-D., in Zahedi, K. (2014) An open letter: To Andreas Schleicher, OECD, Paris. GDM-Mitteilungen 97, str. 31-36.

Morgan, C. (2009) Transnational governance: The case of the OECD PISA. Paper presented to Canadian Political Science Association Conference, 27. maj. Spletna stran: https://www.cpsa-acsp.ca/papers-2009/Morgan. pdf.

Peck, J. (2002) Political economies of scale: Fast policy, interscalar relations, and neoliberal workfare. Economic Geography 78(3), str. 331-360.

Peck, J., in Theodore, N. (2015) Fast policy: Experimental statecraft at the thresholds of neoliberalism. Minnesota: University Press.

Sjøberg, S. (2015) PISA and global educational governance - a critique of the project, its uses and implications. Eurasia Journal of Mathematics, Science \& Technology Education II(I), str. III-I27.

Sjøberg, S. (2018) The power and paradoxes of PISA: Should inquiry-based science education be sacrificed to climb on the rankings?. NorDiNa I 4 (2), str. $186-202$.

St Clair, A. (2006) Global poverty: The co-production of knowledge and politics. Global Social Policy 6(I), str. 57-77.

Stevenson, H. (2017) The 'datafication' of teaching: Can teachers speak back to the numbers?. Peabody Journal of Education $92(4)$, str. 537-557.

Stubbs, P. (2019) Inequality, poverty and education in the post-Yugoslav space: From immobility to inclusion?. Uvodno predavanje na 4. znanstveni konferenci Raziskovanje v vzgoji in izobraževanju: Mednarodni vidiki vzgoje in izobraževanja. Ljubljana: Pedagoški inštitut. Spletna stran: https://www.pei.si/en/conference2019/key-note-stubbs-2019/. 